\title{
The Future of the Field: Highlighting Graduate Student Work in Ukrainian Studies
}

\author{
Nathaniel Ray Pickett \\ University of Kansas
}

$\mathbf{I}_{\mathrm{cos}}$

n the spring of 2017, I organized a Ukrainian Studies graduate student conference called Platforma. The idea for this conference came from two directions. First, as quality graduate student work often remains unseen outside of students' departments, I wanted to create a space specifically for graduate students researching Ukraine, to showcase their work and to provide them an opportunity to get that work published. A second thought came from Ed Johnson, a colleague who at the time was studying at University College London's School of Slavonic and East European Studies, whom I had met while we were both on research fellowships in Kyiv. Ed had participated in the 2015 Platform Ukraine conference at UCL. From our conversations about that conference and my awareness of the relative paucity of opportunities for graduate students in Ukrainian Studies to meet, share, and collaborate, I began to formulate a plan for Platforma.

From the outset, I wanted the conference to be as wide as possible in its disciplinary scope. Because at many universities "Ukrainian Studies" is more of a descriptive orientation than an established academic discipline, graduate students researching aspects of Ukraine-from its politics and economics, to its cultures and languages-work in a variety of departments, programs, and centres. The call for papers, therefore, stated that "Regardless of topic or time period, we want this conference to explore the rich tapestry and exciting new frontiers of Ukrainian Studies." Early in the process of planning the conference, I reached out to East/West: Journal of Ukrainian Studies to propose a special issue of the journal that would feature some of the papers presented at Platforma. Dr. Svitlana (Lana) Krys was enthusiastic in her support of the endeavour, and this volume is the result.

The broad disciplinary scope and the possibility for publication in a well-respected academic journal drew many responses to the call for papers. The proposals submitted came from graduate students in history, geography, Slavic languages and literatures, and political science programs from universities across the US. From the pool of proposals, we were able to organize the Platforma program into four sessions: History and Society, Languages and Literatures, Conflict and War, and Politics and Geopolitics. Each session demonstrated an amazing breadth of topics, subjects, and 
methodologies, testifying to the vibrancy of the current state of Ukrainian Studies.

\section{Figure 1. The Program of the Platforma conference (22 April 2017, University of Kansas).}

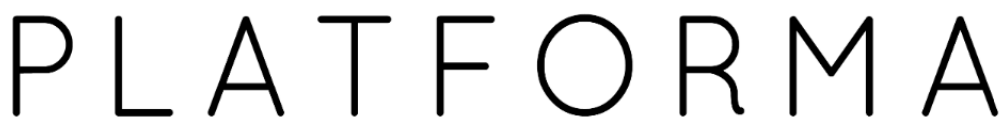

\section{SESSION 1-HISTORY AND SOCIETY}

DISCUSSANT: DR. VITALY CHERNETSKY

Drew Burks, "A Tale of Two Cities: Advertising in Polish and Ukrainian Newspapers and Everyday Life in L'viv during and after the First World War"

Gregory Aimaro, "We Treat All Sorts Of Ailments: A Case Study Of Ukrainian-Jewish Interaction As Seen Through Medical Advertisements"

Oksana Husieva, "Sex, Love, and Marriage in the Holy City: Volodymyr Vynnychenko's Modernist Perceptions of Kyiv in 'Notes of the Snub-Nosed Mephistopheles'"

\section{SESSION 2-LANGUAGES AND LITERATURE}

DISCUSSANT: DR. OLEKSANDRA WALLO

Tetyana Dzyadevych, "How Does Traumatized Dignity Drive Anarchy? Anarchy in UKR by Zhadan and Sanky $a$ by Prilepin"

Sharisa Aidukaitis, "Fighting for Linguistic Autonomy: Historical Roots of the Ukrainian National Language"

Daria Semenova, "'Teaching to Grow up as Worthy Citizens': Soviet Ukrainian Adventure for Youngsters in the 1920-40s"

\section{SESSION 3-CONFLICT AND WAR}

DISCUSSANT: AUSTIN CHARRON

Jordan Sommers, "Between the Hammer and the Anvil': Life and Death among Ethnic Ukrainians in Vinnytsia Oblast, 1941-1943"

Mariia Shynkarenko, "Crimean Tatar Non-Violence National Movement in the Age of Collapse" Paul Aldaya, "Populism Spreads East: Examining the far-right in Ukraine"

\section{SESSION 4-POLITICS AND GEOPOLITICS}

DISCUSSANT: JOHN BIERSACK

Nathaniel Ray Pickett, "To Save a City: Urban-scale Geopolitics in Slavutych, Ukraine"

Kateryna Ruban, "Pro-Life Bills, Post-Soviet Welfare, and Women's Voices: Abortion Policies and Debates in Ukraine Since 1991"

Joshua Demoss, "Anti-Corruption Update in Ukraine: Recent Efforts and Future Proposals" 
The conference concluded with a keynote speech by Dr. Mark Von Hagen. In his remarks, he returned to a question he proposed over two decades ago to frame his discussion on the state of Ukrainian Studies today: "Does Ukraine have a history?" (Von Hagen). He noted that the world of scholarship had expanded from the isolated, ideological work that was pursued during the Cold War to something much more open and free, involving genuine collaboration among Ukrainian, Russian, Western European, and American scholars. Von Hagen observed that, due to the growth and evolution of the study of Ukraine, most Americans and Europeans now have a sense of Ukraine, although some still have trouble distinguishing it from Russia. This, in turn, presents a new form of an old problem for the future of Ukrainian Studies, complicated further by Russia's war with Ukraine. To address this problem, Von Hagen, in his speech, returned to the revolutions of 1917, exploring critical histories of RussianUkrainian relations and the birth of the modern Ukrainian state and nation in war, revolution, and civil war. He ended his remarks by stating that "deconstructing the Russian imperial-national narrative requires familiarization with non-Russian voices. Ukrainians have offered those voices for over a century" (Von Hagen, "Ukrainian Studies").

His keynote address was a fitting bookend to a day of exploring scholarship highlighting Ukrainian voices and experiences. As I was preparing this short introduction, I learned of Dr. Von Hagen's passing, which turns my recollections of the conference bittersweet. Beyond his remarks, Von Hagen was kind and open with everyone involved with Platforma, joining graduate students for lunch, dispensing advice, listening intently, and showing interest in our work. I will be forever grateful to him not just for his contributions to the field but also for his investment in and influence on this latest generation of Ukrainian Studies scholars.

The two articles in this issue that came out of Platforma represent that next generation and evoke the breadth of Ukrainian Studies, from rich work in the humanities and literature to the social sciences and political geography. In the first article, Darya Semenova uses popular adventure books from the 1930s-40s to explore the development of a Ukrainian Soviet identity. She argues that these adventure stories shaped both the borders of the Soviet world and the contours of belonging to the Soviet community for Ukrainian youth. In these stories, the tenets and functions of Socialist Realism permeate, while the stories largely follow the conventions of the adventure story genre, which are rooted in the colonial efforts to bring order and civilization into spaces of chaos, backwardness, and barbarism. This combination reinforces Soviet identity, behaviour, and community at the cost of de-emphasizing the protagonists'-and the young readers'Ukrainian-ness. 
In the second article, I explore from a critical geopolitics framework the political development of Slavutych, the city built to serve workers at the Chornobyl Nuclear Power Plant. I also examine the aftermath of the 1986 disaster and its effects on the families of these workers. I investigate the city's development, the relations among the city's residents, and the residents' involvement in Ukrainian national politics and global organizations. In particular, I look at how Slavutychany leveraged their local expertise-on Chornobyl, on nuclear radiation, on living in spaces of tragedy and disaster-in negotiation with national, transnational, and global organizations to keep the city extant, relevant, and vibrant.

Platforma would not have happened were it not for the support of the Center for Russian, Eastern European, and Eurasian Studies (CREES) and the Department of Geography and Atmospheric Studies at the University of Kansas. My sincerest gratitude goes out to Dr. Vitaly Chernetsky, director of the CREES, who was directly responsible for the success of Platforma; Dr. Shannon O'Lear, who was incredibly supportive; Kathryn Vaggalis, who organized the logistics and planning; discussants Dr. Oleksandra Wallo, Austin Charron, and John Biersack; Bart Redford, Lisa Giullian, and the staff of CREES; Dr. Krys of EWJUS; Dr. Von Hagen; and all of the graduate student participants.

This special section on the Platforma conference is dedicated to the memory of Mark Von Hagen.

\section{Works Cited}

Von Hagen, Mark. “Does Ukraine Have a History?” Slavic Review, vol. 54, no. 3, 1995, pp. 658-73.

---. "Ukrainian Studies and the Centennial of the Revolutions of 1917." Platforma Ukrainian Studies Graduate Student Conference, 22 April 2017, University of Kansas, Lawrence, KS. Keynote Address. 